\title{
MAKNA "SILAS" MENURUT KEARIFAN BUDAYA SUNDA PERSPEKTIF FILSAFAT NILAI: RELEVANSINYA BAGI PEMBERDAYAAN MASYARAKAT MISKIN
}

\author{
Firdaus Saleh ${ }^{1,}$ Soejadi ${ }^{2}$ dan Lasiyo ${ }^{2}$ \\ ${ }^{1}$ Kandidat Doktor Ilmu Filsafat Fakultas Filsafat UGM \\ ${ }^{2}$ Fakultas Filsafat UGM Yogyakarta. \\ E-mail : firdaussaleh3@gmail.com
}

\begin{abstract}
Makna silih asih, silih asah, silih asuh (Silas) sebagai kearifan budaya Sunda mengandung nilai keharmonisan dalam membangun kualitas kemanusiaan, sehingga digunakan sebagai metode pemberdayaan masyarakat miskin. Dalam perspektiffilsafat nilai, makna nilai tersebut memiliki relevansi bagi pemberdayaan masyarakat miskin, karena secara sistematika filsafat menunjukkan bahwa, silih asih mengandung makna nilai ontologis, silih asah mengandung makna nilai epistemologis, dan silih asuh mengandung nilai aksiologis. Pada hakikatnya, manusia miskin diakibatkan oleh ketidakberdayaan mengoptimalkan fungsi susunan hakikat kodrat berupa jiwa (akal, rasa, karsa) dan raganya melalui kehidupannya, sehingga dibutuhkan transformasi nilai pemberdayaan dalam hakikat kodrat manusia yang menjadi subtansi dasarnya. Esensi makna nilai Silas bersifat universal sesuai dengan nilai-nilai Pancasila yang digunakan sebagai metode pemberdayaan masyarakat miskin dengan memiliki ciri-ciri berfikir kefilsafatan, bersifat konseptual, runtut, dan sistematis. Dalam menginternalisasikan makna tersebut, ternyata lebih kondusif pada masyarakat perdesaan daripada perkotaan, tetapi menghadapi kendala mulai tergerusnya nilai tersebut dalam akulturasi dengan budaya luar, sehingga dibutuhkan refungsionalisasi makna Silas dengan melakukan redefinisi dalam dimensi kekinian dan tidak mengubah kandungan subtansi nilainya yang disosialisasikan kepada masyarakatnya.
\end{abstract}

Kata Kunci: Silas, kearifan, filsafat nilai.

\section{THE MEANING OF "SILAS" BASED UPON THE SUNDANESE LOCAL WISDOM PERSPECTIVE OF THE PHILOSOPHY OF VALUE: THE RELEVANCE FOR THE EMPOWERMENT OF THE POOR SOCIETY}

\begin{abstract}
The meaning of silih asih (loving each other), silih asah ( educating each other), and silih asuh (caring each other) (Silas) as the Sundanese Local Wisdon contains the harmony value in constructing the quality of humane, so that it is used as a method of empowering the poor society. In the perspective philosophy of value, the meaning of that value has relevance toward the empowerment of the poor society, since based upon the philosophical way; it shows that loving each other contains the ontological value; educating each other contains the meaning of epistemological value, and caring each other contains axiological value. Essentially, the poor people was caused by having lack power to optimize the functions of basic capacity in the form of soul (mind, feeling, and deed/action) and the physical appearance through a life. Therefore, it needs a transformation of empowerment value in the essence of human being that becomes the essential substance. The essence of Silas meaning is universal that is in accordance with Pancasila values used as the method of empowering the poor society having the characteristics of: philosophical thinking, conceptual, coherent, and systematic. In internalizing those meanings, it is more conducive in suburb people than the rural ones. However, this encounters some obstacles of decreasing those values in acculturation with outside culture, that it requires to refunctionalize the meaning of Silas by conducting redefinition in present dimension without changing the content of its value essence.
\end{abstract}

Key words: Silas, wisdom, philosophy of value. 


\section{PENDAHULUAN}

Dalam kehidupan masyarakat Sunda terdapat kearifan budaya yang meletakkan pentingnya keharmonisan hubungan antarmanusia dalam kehidupan masyarakatnya yang saling ketergantungan dengan tidak melupakan jati-diri dan habitatnya masing-masing, yang bertujuan untuk meningkatkan kualitas kemanusiaan. Kearifan budaya tersebut terdapat dalam konsep silih asih, silih asah, silih asuh (silas) yang mengandung nilai moral kebaikan dalam membangun kebersamaan melalui kehidupan masyarakatnya. Karena itu, konsep tersebut diadopsi sebagai landasan nilai moral dalam pemberdayaan masyarakat miskin melalui Program Nasional Pemberdayaan Masyarakat (PNPM) Mandiri Perkotaan maupun Perdesaan di tatar Pasundan.

Fenomena tersebut di atas perlu dipertanyakan kembali terhadap eksistensi konsep nilai itu dalam program pemberdayaan masyarakat miskin pada dimensi kekinian, karena dalam kehidupan masyarakat Sunda terdapat kecenderungan mulai tergerusnya nilai-nilai kebersamaan yang berkembang ke arah individulistik dan materialistik. Bagaimana esensi makna Silas menurut kearifan budaya Sunda dalam perspektif filsafat nilai relevansinya bagi pemberdayaan masyarakat miskin di perkotaan dan perdesaan. Karena dalam kehidupan masyarakat Sunda, permasalahan kemiskinan merupakan suatu hal bersifat mendasar yang membutuhkan penanggulangan melalui pemberdayaan masyarakat yang bertumpu kepada nilainilai kearifan budayanya. Hal ini menarik untuk dikaji agar memberikan manfaat secara akademis maupun praksis berkaitan dengan pelaksanaan Program Nasional Pemberdayaan Masyarakat (PNPM) Mandiri Perdesaan dan Perkotaan di dua lokasi penelitian tersebut.

\section{METODE}

Penelitian ini menggunakan metode penelitian kualitatif dalam bidang ilmu filsafat dengan berobjek formal berupa filsafat nilai dan objek materialnya adalah makna silih asih, silih asah, silih asuh (silas) menurut kearifan budaya Sunda. Cara penelitian dilakukan dengan mengumpulkan data yang dibutuhkan menggunakan studi kepustakaan (library research) sebagai data primer yang berkaitan dengan literatur filsafat nilai dan filsafat bahasa dalam memahami makna Silas sebagai kearifan budaya Sunda, yang diperoleh dari buku, jurnal ilmiah, laporan, majalah, dan berbagai jenis penerbitan ilmiah lainnya. Di samping itu, penelitian ini juga ditunjang oleh studi lapangan (field research) terhadap objek penelitian sebagai data sekunder melalui wawancara secara mendalam dengan menggunakan kuesioner (daftar pertanyaan), untuk memperoleh data penunjang yang bersumber dari informan di lokasi penelitian pada masyarakat perkotaan yang dipilih Kelurahan Pungkur Kecamatan Regol Kota Bandung, karena kelurahan ini dinilai terbaik dalam melaksanakan PNPM Mandiri Perkotaan. Sedangkan masyarakat perdesaan dilakukan Kecamatan Rancakalong Kabupaten Sumedang melaksanakan PNPM Mandiri Perdesaan berbasis Budaya Sunda dalam Program Sauyunan.

Prosedur penelitian dilakukan melalui pengumpulan data kepustakaan dan data lapangan yang diolah melalui reduksi dan display data dalam pengorganisasian data sesuai kepentingannya, kemudian dianalisis dengan menggunakan analisis metode: historis, berkaitan dengan analisis terhadap objek penelitian yang sumber datanya bisa dihayati di masa lampau dan masa kini menurut perkembangan zaman; semantik, objek penelitian ditelusuri menurut asal-usul kata secara etimologis dalam memahami arti yang sesungguhnya menurut kaidah bahasa yang digunakan; sintaksis, untuk memahami hubungan kata dalam suatu kalimat dalam perspektif ilmu tata-kalimat dari segi ilmu bahasa; hermeneutika, digunakan untuk menelaah keseluruhan data yang dihimpun dari sudut makna terkandung dalam objek penelitian yang direfleksikan dalam kerangka pemikiran masa kini dengan memperhatikan masa yang telah berjalan; heuristika, bertujuan untuk manangkap arti melalui verstehen (pemahaman) atas inti 


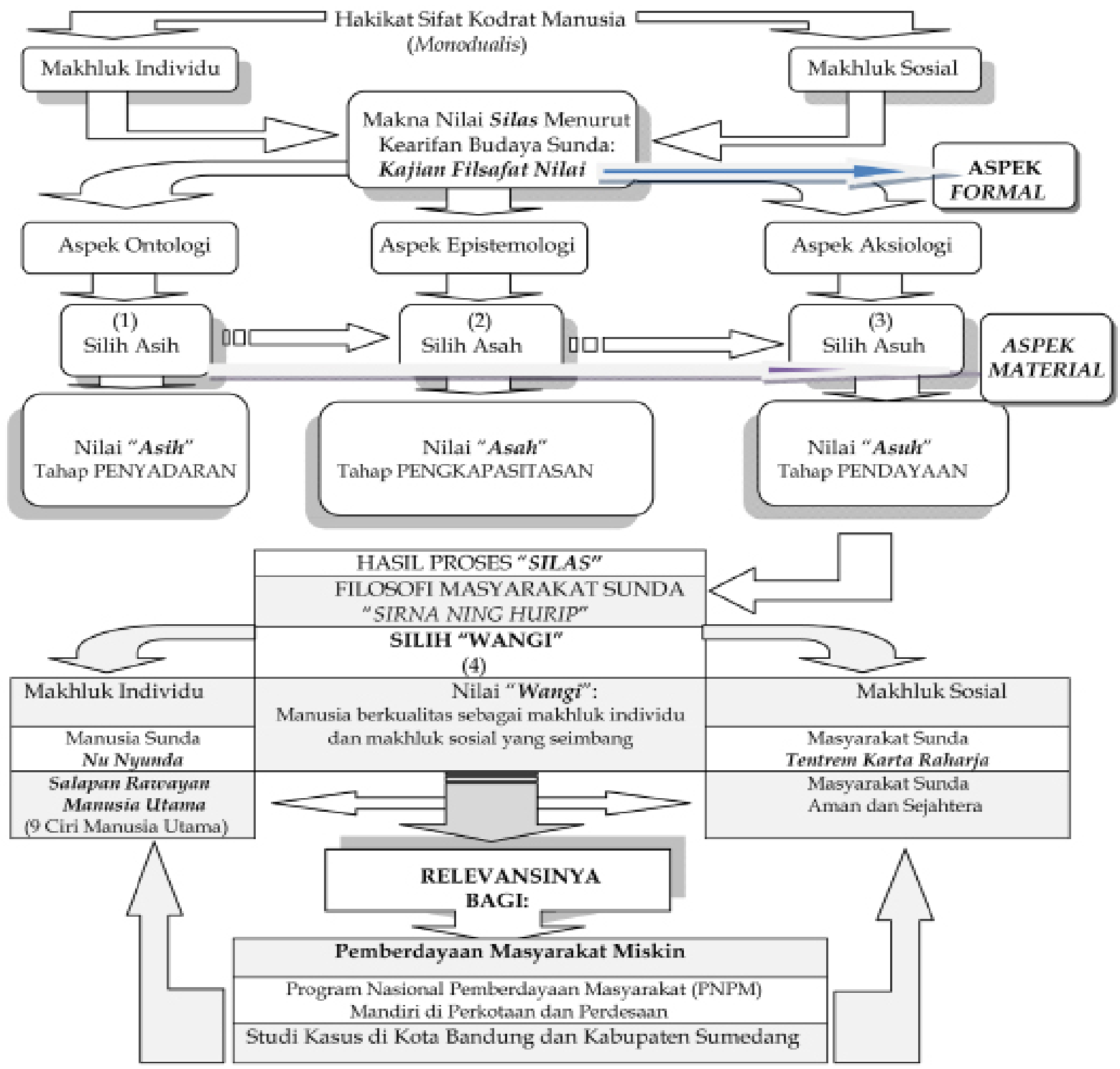

Gambar 1. Alur Kajian Makna Silas Menurut Kearifan Budaya Sunda Perspektif Filsafat Nilai: Rel vansinya bagi Pemberdayaan Masyarakat Miskin

'fenomena' realitas objektif yang merupakan bagian tidak terpisahkan dengan metode hermeneutika; interpretasi, digunakan meng interpretasikan makna yang terkandung dalam objek penelitian pada dimensi ruang dan waktu untuk menjelaskan bagaimana perubahan terjadi; deskripsi, digunakan untuk mengungkapkan objek material yang dikaji agar mendapat gambaran secara jelas adanya peristiwa yang dinilai akurat berhubungan dengan objek material penelitian. Pada teknik tahapan analisis data ini, juga digunakan pendekatan secara filosofis melalui refleksi kefilsafatan dalam bentuk, pendekatan: spekulasi, bertujuan memahami pengalaman masyarakat Sunda dalam mene- rapkan konsep Silas sebagai kearifan lokal yang direnungkan secara menyeluruh untuk mengungkap kandungan makna nilainya; analisis, untuk menganalisis keseluruhan data yang diabstaksi untuk menangkap makna subtansial yang menjadi esensi objek penelitian; komprehensi, bertujuan menganalisis keseluruhan data dengan menggunakan metode penelitian filsafat untuk memecahkan rumusan masalah penelitian secara utuh dan evaluasi, bertujuan untuk meneliti konsistensi logis antara keseluruhan data yang dianalisis melalui cara dan prosedur penelitian untuk menjawab rumusan masalah sesuai dengan landasan teori yang dipilih dalam penelitian filsafat. 


\section{HASIL DAN PEMBAHASAN}

Hasil penelitian menunjukkan bahwa kearifan lokal budaya Sunda terdapat dalam budaya ide, budaya aktifitas, dan budaya artefak melalui unsur-unsur kebudayaan, yang dijadikan pandangan hidup dan pedoman hidupnya dalam hubungan dengan Tuhan, alam semesta dan sesama manusia. Makna kearifan budaya Sunda merupakan suatu kearifan lokal (local wisdom) yang terdapat dalam komunitas masyarakatnya, baik muncul dalam tradisi lisan maupun tulisan sebagai suatu kepribadian menjadikan identitas kultural masyarakat berbentuk nilai, norma, etika, kepercayaan, adat-istiadat dan aturan khusus yang teruji kemampuannya menjadikan kebiasaan, sehingga dapat bertahan terus-menerus (Sartini, 2009: 11). Sumber kearifan budaya Sunda terdapat dalam kebudayaan masyarakat masa lalu dan masa kini bersumber dari tradisi lisan berbentuk carita, nasihat, pantun, uga, folklor lisan yang juga terdapat dalam bukti-bukti tertulis berbentuk prasasti dan situs; naskah (manuscript) seperti babad, serat, carita, wawacan, karya sastra lainnya yang bersifat tertulis. Subtansi yang terkandung dalam kearifan lokal budaya Sunda adalah nilai moral kebaikan sebagai suatu keunggulan budaya mengungkap pikiran, perasaan, dan pengetahuan yang mengandung kebijaksanaan (wisdom) yang terdapat dalam masyarakat sesuai identitas budayanya.

Dalam masyarakat Sunda terdapat kearifan budaya membangun kehidupan manusia dengan meletakkan pentingnya keharmonisan hubungan antarmanusia dalam kehidupan masyarakat yang hidup saling ketergantungan dengan tidak melupakan jatidiri dan habitatnya untuk meningkatkan kualitas kemanusiaan, terdapat dalam konsep silih asih, silih asah, dan silih asuh (silas) (Suryalaga, 2010:126). Konsep silas diidentifikasi, dikembangkan dalam kebudayaan Sunda masa lalu pada masa kepemimpinan Prabu Siliwangi sebagai realisasi 'keluhuran hati budi nurani' yang kemudian unsur-unsurnya digali oleh Bung Karno sebagai falsafat Pancasila (Hilmiana, 2009: 31).
Makna konsep silas dalam perspektif hermeneutik, memiliki keterkaitan dengan makna yang terkandung dalam kata pembentuknya, berupa kata silih dan kata asih, asah, asuh yang menjadi esensi kandungan nilainya. Kata silih berarti saling, mengandung makna nilai transformasi yang bersifat resiprokal dan saling memberikan respon dengan penuh kesantunan. Kata asih berarti cinta, mengandung makna nilai ontologis bahwa keberadaan 'asih' berasal dari Tuhan Yang Maha Pengasih (Qur'an, 55: 1,3), sehingga nilai asih menjadi landasan kehidupan dalam membangun keharmonisan hidup manusia. Kata asah berarti menajamkan, mengandung makna nilai epistemologi bahwa kemampuan me-ngasah akal, rasa, dan karsa dalam diri manusia akan menghasilkan pengetahuan dan ilmu pengetahuan dalam kehidupannya. Kata asuh berarti membimbing, mengandung makna nilai aksiologi bahwa dalam membangun hubungan silaturrahmi didasari atas saling menghargai kewajiban dan hak asasi manusia berlandaskan pada nilai-nilai keharmonisan dalam membangun kualitas kemanusiaan.

Perpaduan kata silih dengan masingmasing kata asih, asah, asuh menjadikan kata majemuk mengandung makna transformasi nilai yang bersumber dari subtansi makna nilai: asih, asah, asuh dalam kehidupan antar manusia dalam realitas kehidupan masyarakat, sehingga terbangun harmonisasi yang saling ketergantungan untuk meningkatkan kualitas kemanusiaan. Orientasi nilai yang terkandung dalam makna silas pada hakikatnya untuk meningkatkan kualitas sumberdaya manusia dalam kehidupan sosialnya, sehingga dapat dijadikan metode pemberdayaan manusia dalam kehidupan masyarakat sebagai landasan pendidikan masyarakat, baik pendidikan keluarga, pendidikan formal dan non-formal maupun pendidikan di lingkungan masyarakat.

Fenomena kemiskinan yang terjadi di lokasi penelitian menujukkan bahwa, manusia miskin pada hakikatnya akibat ketidakmampuan memenuhi kebutuhan hidupnya secara 'layak', karena 
ketidakberdayaan mengoptimalkan fungsi susunan hakikat kodrat berupa jiwa (akal, rasa, karsa) dan raganya dalam satukesatuan yang bersifat monodualis pada struktur sosial masyarakat yang kurang memberikan peluang atas keberdayaan dirinya. Secara ontologis, bahwa keberadaan manusia miskin pada hakikatnya akibat ketidakmampuan mengoptimalkan potensi unsur jiwa berupa akal dalam menghasilkan pemikiran yang produktif menjadikan dirinya tidak miskin, rasa yang dimiliki belum mampu saling simpati, empati, dan peduli dalam membangun kehidupan yang harmonis, karsa yang dimilikinya belum mampu memunculkan budaya ide yang kreatif dan inovatif yang dapat direalisasikan dalam budaya aktifitas untuk meningkatkan kesejahteraan hidupnya.

Beranjak dari subtansi kemiskinan dalam diri manusia yang berkembang dalam kehidupan masyarakatnya, maka akar penyebab kemiskinan dapat diakibatkan oleh faktor kultural dan struktural yang bersifat multidimensional. Secara epsitemologi, bahwa kebudayaan kemiskinan disebabkan oleh perilaku "menyimpang", dalam arti budaya miskin yang tetap dipertahankan pada strata terbawah masyarakat kapitalistik dalam merespon kondisi deprivasi ekonomi. Dalam pandangan struktural masyarakat, bahwa manusia miskin pada kehidupan masyarakat strata terbawah mengalami tekanan dari luar dirinya yang bersifat eksploitatif, sehingga ketidakmampuan menghadapi tekanan tersebut berakibat ketidakberdayaan dirinya. Kehidupan manusia miskin yang terjadi dalam suatu rumah-tangga miskin yang hidup dalam suatu daerah, ternyata memiliki mata-rantai keterkaitan yang bersifat multidimensional yang menurut Chambers (1983:145-148) diakibatkan faktor; kemiskinan dalam arti tidak terpenuhinya standar hidup layak, kelemahan jasmani, isolasi dalam arti bahwa hidupnya dalam masyarakat kurang memperoleh aksebilitas bagi kehidupannya, karena keterpencilan atau sikap menyingkirkan dirinya akibat sikap rendah diri, kerentanan dalam artiketidakpastian atas penghidupannya menghadapi pemenuhan untuk hidup 'layak', ketidakberdayaan dalam arti ketidakmampuan diri menghadapi tekanan kaum yang lebih kuat. Secara aksiologis, bahwa manusia miskin tidak terpenuhinya kebutuhan nilai-nilai utama yang berkaitan dengan pemenuhan kebutuhan dasar manusia secara layak, berupa sandang, pangan, papan, kesehatan, pendidikan, pekerjaan, dan lain-lain, sehingga terjadi jurang (gap) dalam realitas sosial pada kebudayaan masyarakatnya (Ala, 1981: 5,10). Penyebabnya ketidakmampuan memenuhi nilai-nilai utama ini, diidentifikasi dalam kebudayaan manusia miskin adalah dimilikinya nilai-nilai negatif berupa perilaku malas, kurang menghargai waktu, rendah diri, boros, tidak produktif, tidak kreatif dan inovatif, dan sifat-sifat perilaku negatif lainnya.

Oleh karena itu, untuk menanggulangi kemiskinantersebutdilakukanpemberdayaan masyarakat miskin melalui Program $\mathrm{Na}-$ sional Pemberdayaan Masyarakat (PNPM) Mandiri Perkotaan dan Perdesaan. Landasan pemberdayaan masyarakat miskin dalam hakikat kodrat manusia bertumpu pada 'daya', yang dimaknai sebagai suatu kekuatan yang ada dalam jiwa pada kesatuan raganya. Secara ontologi, bahwa keberadaan daya pada diri manusia terdapat pada susunan hakikat kodrat berupa jiwa yang terdiri dari unsur akal, rasa, karsa dalam kesatuan badannya yang mengandung unsur benda mati (kimiawi), sifat-sifat naluriah seperti binatang, dan sifat-sifat yang yang ada seperti tumbuhan yang pada hakikat keberadaannya berasal dari sumber segala 'kekuatan', yaitu Tuhan Maha Kuasa (kausa prima). Ketidakberdayaan mengoptimalkan fungsi susunan hakikat kodrat berupa kesatuan jiwa (akal, rasa, karsa) dan raganya dalam diri manusia yang bersifat monodualis menjadi penyebab manusia kurang atau tidak berdaya, sehingga berakibat pada kemiskinan dirinya. Manusia yang kurang atau tidak berdaya dalam memenuhi kebutuhan hidupnya secara 'layak' terdapat pada suatu keluarga dalam komunitas masyarakat yang berada pada suatu wilayah tertentu disebut masyarakat miskin. 
Pemberdayaan masyarakat miskin pada hakikatnya adalah mendorong menumbuhkan kekuatan yang bersumber pada susunan hakikatnya kodrat pada diri manusia miskin, yang diinisiasikan melalui tranformasi nilai pemberdayaan yang berasal dari stimulasi orang lain atau disebut 'pemberdaya', sehingga tumbuh berkembang keberdayaan dirinya menjadikan manusia berdaya yang hidupnya tidak miskin. Esensi dari transformasi nilai keberdayaan dalam kehidupan manusia terjadi melalui interaksi sosial berlandaskan pada sifat hakikat kodrat manusia dalam menyeimbangkan dirinya sebagai makhluk individu dan makhluk sosial yang bersifat monodualis. Ketidakseimbangan manusia sebagai makhluk individu dalam keadaan miskin akan mencari solusi dengan berusaha dan berikhtiar memenuhi kebutuhan hidupnya secara 'layak', sebagai upaya meningkatkan keberdayaan dirinya. Dalam mencari solusi tersebut membutuhkan stimulasi bantuan orang lain sebagai makhluk sosial. Karena itu, pada diri manusia yang memiliki keberdayaan harus selalu ada kemampuan untuk memberikan kepada diri sendiri dan orang lain sebagaimana semestinya sebagai makhluk sosial, sehingga menjadikan kewajiban moral sesuai nilai kemanusiaan yang adil dan beradab. Dalam kehidupan sosial inilah terjadinya pemberdayaan masyarakat miskin, yang pada hakikatnya mengandung 'nilai transformasi' dalam mendorong fungsi susunan hakikat kodratnya yang bersifat monodualis menjadi lebih optimal dalam mengatasi kemiskinannya sebagai sebagai watak keadilan (Notonagoro, 1995: 98). Transformasi nilai ini terjadi dalam proses pemberdayaan masyarakat melalui tahapan; penyadaran, pengkapasitasan, dan pendayaan (Wrihatnolo \& Nugroho, 2007: 2). Dalam implementasinya, program pemberdayaan masyarakat miskin, baik dalam masyarakat perkotaan maupun perdesaan masih berkutat pada tahapan 'pengkapasitasan', karena belum sepenuhnya menyentuh esensi kemiskinan manusia berupa nilai keberdayaan dalam tahapan pendayaan dengan mengoptimalkan hakikat kodratnya yang bersifat monopluralis sebagai landasannya.
Memaknai pemberdayaan masyarakat miskin dalam perspektif epistemologi, pada hakikatnya mentranformasikan nilai-nilai pengetahuan yang bersumber dari akal, rasa, dan karsa dalam dirinya melalui kehidupan masyarakat, agar memiliki keberdayaan diri dalam memenuhi kebutuhan hidupnya secara 'layak'. Nilai-nilai pengetahuan ini berkaitan dengan pemenuhan kelangsungan kehidupan dalam penghidupannya yang bersifat praksis, baik dari aspek ekonomi, sosial, budaya, dan politik. Sedangkan dalam perspektif aksiologis, bahwa dalam pemberdayaan masyarakat terjadinya transformasi nilai-nilai positif dari manusia yang tidak miskin (pemberdaya) seperti; jujur, peduli, kerja keras, rajin, kreatif, inovatif, menghargai waktu, produktif, percaya diri, selalu mau belajar, dan nilainilai positif lainnya kepada manusia miskin yang memiliki nilai negatif seperti malas, rendah diri, tidak menghargai waktu, boros, tidak produktif dan kreatif, dan nilai negatif lainnya menjadi nilai positif. Oleh karena manusia sebagai makhluk ciptaan Tuhan diberi otonomi dan kewenangan untuk mengembangkan eksistensi dirinya, sehingga segala tindakan merupakan tanggungjawab diri pribadi dan juga kepada Tuhannya. Karena itu, membangun keberdayaan diri dalam mengoptimalkan fungsi susunan hakikat kodrat yang dimilikinya merupakan kewajiban moral dalam kehidupan sosial berdasarkan sifat hakikat kodratnya sebagai makhluk individu dan makhluk sosial yang seimbang dalam membangun eksistensi diri sebagai makhluk yang berdiri sendiri. Secara ontologis, keberdayaan manusia pada hakikatnya merupakan suatu tuntutan bagi keberadaan eksistensi diri pribadi sebagai makhluk Tuhan yang telah mengaruniakan susunan hakikat kodratnya berupa jiwa dan raganya, sehingga menjadikan kewajiban agar patuh dan taat melaksanakan perintahNya dan menjauhi laranganNya. Esensi makna nilai silas menurut kearifan budaya Sunda pada hakikatnya merupakan upaya meningkatkan kualitas sumberdaya manusia, karena mengandung transformasi nilai pemberdayaan manusia. Secara ontologi keberadaan kehidupan manusia di 
dunia atas 'asih'nya Tuhan Yang Pengasih, sehingga kedudukan hakikat kodratnya sebagai makhluk Tuhan dan juga makhluk berdiri sendiri sebagai satu-kesatuan bersifat monodualis. Nilai asih yang dari Tuhan inilah menjadi landasan dalam membangun hubungan harmonisasi kehidupan untuk meningkatkan kualitas kemanusiaan. Nilai asih sesama manusia merupakan nilai moral kebaikan dalam diri manusia bersumber dari hati nurani yang dilandasi nilai religius yang bersumber dari dalam jiwa diri manusia. Karena itu, nilai asih dalam bentuk rasa asih pada setiap orang akan berbeda-beda, ada yang bependapat sebagai suatu 'kewajiban moral' sebagaimana pemikiran filsuf Immanuel Kant dan landasan yang digunakan masyarakat kita lebih dipengaruhi oleh nilai religius, tetapi ada yang berpendapat sebagai suatu 'kesukarelaan' yang didasarkan pada kesadaran dirinya saja sebagaimana pemikiran Mix Scheler (Wahana, 2004). Karena itu, manusia sebagai makhluk Tuhan berkewajiban moral melakukan silas dalam pemberdayaan masyarakat miskin yang dilandasi nilai moral kebaikan, yang diamanatkan Tuhannya untuk membangun kualitas kemanusiaan. Upaya ini dilakukan untuk mengoptimalkan fungsi susunan hakikat kodrat jiwa (akal, rasa, karsa) dan raganya yang merupakan esensi makna nilai silas dalam proses pemberdayaan masyarakat miskin.

Dalam kehidupan sosial sifat hakikat kodrat manusia ialah selalu berusaha membangun keseimbangan sebagai makhluk individu meningkatkan kualitas diri, sehingga pada saat mengalami kekurangberdayaan membutuhkan transformasi nilai pemberdayaan dari orang lain. Sebaliknya, pada saat manusia mengalami keberdayaan diri sebagai makhluk sosial, maka merupakan kewajiban moral mentransformasikan nilai pemberdayaan kepada orang lain yang mengalami kekurangberdayaan sebagaimana mestinya. Dalam membangun kehidupan masyarakat yang berharkat dan bermartabat inilah dibutuhkan pemahaman warga masyarakat agar dalam realitasnya dapat menyeimbangkan dirinya sebagai makhluk individu berkualitas agar peduli dalam bentuk materi dan non-materi kepada warga masyarakat lainnya yang mengalami kekurangberdayaan diri sebagai makhluk sosial melalui proses pemberdayaan dalam kehidupan masyarakat.

Proses pemberdayaan masyarakat yang terkandung dalam konsep Silas menurut kearifan budaya Sunda memiliki ciriciri berfikir kefilsafatan. Menurut Kattsoff (1987: 6-15), bahwa berfikir kefilsafatan berusaha menyusun suatu bagan konseptual yang harus bersifat koheren (runtut) dan sistematis, tidak terdapat suatu pertentangan dan terdapat suatu hubungan yang memiliki saling keterkaitan mencapai satu tujuan. Tahapan pemberdayaan yang dimulai dari tahap 'penyadaran' dilandasi nilai asih dalam interaksi sosial berupa silih asih, tahap 'pengkapasitasan' dilandasi nilai asah dalam interaksi sosial berupa silih asah, tahap 'pendayaan' dilandasi nilai asuh dalam interaksi sosial berupa silih asuh. Keberhasilan membangun nilai silas adalah meningkatkan kualitas kemanusiaan dalam interaksi sosial masyarakat yang menunjukkan terjadinya men-Silih-Wangikeun. Artinya, wangi menunjukkan kualitas kemanusiaan yang dapat ditrasformasikan darimasyarakat yang kurang berdaya menjadi manusia utama yang disebut Manusa Sunda

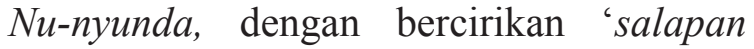
rawayan' manusia utama berupa : cageur, bageur, bener, pinter, singer, teger, pangger, wanter, cangker, sehingga menunjang tercapainya kehidupan masyarakat yang tengtrem kartaraharja (Saleh, 2010:33).

Silas merupakan kearifan lokal (local wisdom) budaya Sunda, tetapi makna nilai yang terkandung di dalamnya bersifat universal sesuai dengan nilai-nilai Pancasila, baik terkandung dalam nilai Ketuhanan, Kemanusiaan, Persatuan, Kerakyatan, maupun Keadilan. Nilai-nilai yang bersifat universal berlaku umum yang terdapat dalam Silas diakui kebenarannya, berkaitan dengan kemanusiaan sebagai wawasan umat manusia di dunia yang bertumpu pada pengakuan pada martabat manusia berlandaskan kodratnya (Magnis Suseno, 1999: 90). Adapun nilai-nilai Pancasila digali dari kearifan budaya masyarakat 
Indonesia yang berasal dari berbagai kearifan budaya dari ragam suku-bangsa termasuk di dalamnya budaya Sunda sebagaimana hasil penelitian disertasi Hilmiana (2009).

Kebudayaan Sunda mengalami akulturasi dengan berbagai kebudayaan masyarakat lainnya termasuk dengan budaya global, sehingga berpengaruh positif maupun negatif dalam perkembangan kebudayaan masyarakatnya. Pengaruh negatif terhadap kebudayaan Sunda dari adanya akulturasi dengan budaya global, menunjukkan bahwa nilai-nilai individualistik dan materialistik yang dikembangkan kapitalisme modern telah mempengaruhi pola kebudayaan (pattern of culture) masyarakatnya, yang terindentifikasi mulai tergerusnya nilai-nilai sosial dalam membangun kebersamaan yang terkandung dalam nilai silas ini. Karena itu, dalam menginternalisasikan nilai silas dalam program pemberdayaan masyarakat miskin menghadapi kendala berupa: (a) mulai tergerusnya nilai silas dalam akulturasi dengan budaya luar, (b) kurangnya pemahaman masyarakat mengenai hubungan relevansi makna nilai silas dengan program tersebut, (c) kurangnya kesadaran kolektif mereaktualisasikan dalam realitas kehidupan melalui program ini, sehingga diperlukan refungsionalisasi makna nilai silas dalam berbagai program pemberdayaan masyarakat miskin yang disosialisasaikan kepada masyarakatnya. Dalam menginternalisasikan nilai silas dalam program pemberdayaan masyarakat miskin melalui Program Nasional Pemberdayaan Masyarakat (PNPM) Mandiri Perkotaan dan Perdesaan, ternyata lebih kondusif pada masyarakat perdesaan karena lebih kuat membangun kebersamaan hidup dalam mengembangkan nilai sosial daripada masyarakat perkotaan.

\section{SIMPULAN}

Esensi kearifan budaya Sunda mengandung nilai moral kebaikan dalam kehidupan masyarakat Sunda masa lalu hingga kini menjadi pedoman dan pandangan hidup masyarakatnya, yang muncul dalam wujud budaya dan unsur-unsur kebudayannya. Nilai moral kebaikan dalam membangun kebersamaan meningkatkan kualitas kemanusiaan pada kehidupan masyarakatnya terdapat dalam konsep silas. Makna silas dalam kearifan budaya Sunda menurut perspektif sistematika filsafat menunjukkan bahwa, silih asih mengandung makna nilai ontologis, silih asah mengandung makna nilai epistemologis, silih asuh mengandung makna nilai aksiologis. Manusia miskin pada hakikatnya diakibatkan ketidakberdayaan mengoptimalkan fungsi susunan hakikat kodrat berupa jiwa (akal, rasa, karsa) dan raganya dalam kehidupannya, sehingga dibutuhkan transformasi nilai pemberdayaan dalam hakikat kodrat manusia yang menjadi esensi pemberdayaan masyarakat miskin.

Dalam proses pemberdayaan masyarakat dilakukan melalui suatu tahapan yang memiliki relevansi dengan konsep silas, yang dimulai dari tahap 'penyadaran' berlandaskan nilai asih melalui silih asih, tahap 'pengkapasitasan' berlandaskan nilai asah melalui silih asah, dan tahap 'pendayaan' berlandaskan nilai asuh melalui silih asuh. Keberhasilan proses pemberdayaan masyarakat berlandaskan nilai silas yang berjalan baik dan benar dalam kehidupan masyarakat akan menghasilkan silih wangi, yang menunjukkan bahwa makna nilai wangi sebagai kualitas manusia utama dalam perspektif makhluk individu, sehingga dalam kehidupan sosial akan menghasilkan masyarakat tengtrem kartaraharja. Oleh karena itu, esensi makna nilai silas ini bersifat universal sesuai nilainilai Pancasila yang digunakan sebagai metode pemberdayaan masyarakat memiliki ciri-ciri berfikir kefilsafatan, yaitu bersifat; konseptual, koheren (runtut), dan sistematis. Menginternalisasikan makna nilai silas dalam program pemberdayaan masyarakat miskin lebih kondusif pada masyarakat perdesaan daripada perkotaan, karena tergerusnya nilai-nilai sosial lebih kuat terjadi pada masyarakat perkotaan yang lebih bersifat individualistik. Kendala lain yang dihadapi dalam menginternalisasikan 
berupa; kurangnya pemahaman masyarakat mengenai hubungan relevansi makna nilai silas dengan program tersebut, mulai tergerusnya nilai silas dalam akulturasi budaya, kurangnya kesadaran kolektif mereaktualisasikannya dalam realitas kehidupan masyarakat, sehingga diperlukan refungsionalisasi makna nilai silas sebagai upaya revitalisasi dan mengatualisasikan dalam program pemberdayaan masyarakat miskin yang disosialisasikan kepada masyarakat.

\section{DAFTAR PUSTAKA}

Adiwidjaya, Soelaiman B. 1994. The University Mission in The Realization of The "Silih Asih, Silih Asah, Silih Asuh" Academic Life.

Ala, Andre Bayo. 1981. Kemiskinan dan Strategi Memerangi Kemiskinan, Yogyakarta: Liberty.

Chamber, Robert, (terjemahan). 1987. Rural Development: Putting the Last First, diterjemahkan oleh Pepep Sudradjat dalam buku Pembangunan Desa: Mulai dari Belakang, Jakarta: Cetakan Kedua, LP3ES.

Hilmiana. 2009. Pengaruh Perilaku Budaya Sunda dan Kepemimpinan Serta Orientasi Gender Terhadap Etos Kerja Di Lingkungan Bisnis Perbankan di Kotamadya Bandung, Program Doktor Ilmu Ekonomi, Program Pascasarjana, Bandung: Universitas Katolik Parahyangan, Disertasi tidak diterbitkan.

Junus, H. Mahmud. 1996. Tarjamah Al Quran al karim, Bandung: Cetakan Kesepuluh, Alma'arif.
Kattsoff, Louis O., (terjemahan). 1987. Pengantar Filsafat, diterjemahkan oleh Soejono Soemargono. Yogyakarta: Tiara Wacana.

Kaelan. 2005. Metode Penelitian Kualitatif bidang Filsafat, Yogyakarta: Paradigma.

Magnis Suseno, Franz. 1999. Berfilsafat Dari Konteks, Cetakan Ketiga, Jakarta: Gramedia Pustaka Utama.

Notonagoro. 1995. Pancasila Secara Ilmiah Populer, Jakarta: Bumi Aksara.

Sartini, 2009, Mutiara Kearifan Lokal Nusantara, Yogyakarta: Kepel Press.

Saleh, Firdaus. 2010. Orientasi Nilai Silih Asih, Silih Asah, Silih Asuh Dalam Perspektif Kearifan Lokal Budaya Sunda Sebagai Landasan Pembangunan CSR Di Jawa Barat, dalam Warta Bappeda Provinsi Jawa Barat, diterbitkan Bappeda Provinsi Jawa Barat, Volume 15, Nomor 4: 29 - 36 .

Suryalaga, R. Hidayat. 2010. Kesundaan Rawayan Jati, Bandung: Yayasan Nur Hidayah.

Wahana, Paulus. 2004. Nilai Etika Aksiologis Max Scheler, Yogyakarta: Cetakan Pertama, Kanisius.

Wrihatnolo, Randy R. \& Dwidjowijoto, Riant Nugroho. 2007. Manajemen Pemberdayaan: Sebuah Pengantar dan Panduan Untuk Pemberdayaan Masyarakat. Jakarta: Cetakan Pertama, Elex Media Komputindo. 